\title{
Plasma membrane localization of the GFL receptor components: a nexus for receptor crosstalk
}

\author{
Christopher R. Donnelly ${ }^{1} \cdot$ Brian A. Pierchala $^{2}$ (D) \\ Received: 19 March 2020 / Accepted: 4 June 2020 / Published online: 7 August 2020 \\ (C) The Author(s) 2020
}

\begin{abstract}
The glial cell line-derived neurotrophic factor (GDNF) family ligands (GFLs) comprise a group of four homologous and potent growth factors that includes GDNF, neurturin (NRTN), artemin (ARTN), and persephin (PSPN). The survival, growth, and mitotic activities of the GFLs are conveyed by a single receptor tyrosine kinase, Ret. The GFLs do not bind directly to Ret in order to activate it, and instead bind with high affinity to glycerophosphatidylinositol (GPI)-anchored coreceptors called the GDNF family receptor- $\alpha \mathrm{s}(\mathrm{GFR} \alpha \mathrm{s})$. Several mechanisms have recently been identified that influence the trafficking of Ret and GFR $\alpha \mathrm{s}$ in and out of the plasma membrane, thereby affecting their availability for ligand binding, as well as their levels by targeting to degradative pathways. This review describes these mechanisms and their powerful effects on GFL signaling and function. We also describe the recent discovery that 775 and Ret form a signaling complex, also regulated by plasma membrane shuttling, that either enhances GFL survival signals or p75 pro-apoptotic signals, dependent on the cellular context.
\end{abstract}

Keywords Ret $\cdot$ GFR $\alpha \cdot$ Plasma membrane $\cdot$ Intracellular trafficking $\cdot$ GDNF $\cdot$ GFLs $\cdot$ TGF- $\beta$ regulation

\section{Introduction}

In the past, illustrations detailing neurotrophic factor signaling pathways often indicated relatively simplistic interactions between well-established ligand-receptor pairs, with each complex separately leading to the activation of downstream signaling cascades controlling a variety of cell fates. Within the neurotrophin family, for example, nerve growth factor (NGF) binds to TrkA, brain-derived neurotrophic factor (BDNF) and neurotrophin-4 (NT-4) bind to TrkB, and neurotrophin-3 binds to TrkC, and all four ligands can bind with reduced affinity to p75 (Reichardt 2006). However, as our understanding of neurotrophic factor signaling has evolved over the last several decades, we have come to appreciate that a highly complex set of interactions exists between neurotrophic factor

Brian A. Pierchala

brpierch@iu.edu

1 Department of Anesthesiology Center for Translational Pain Medicine, Duke University Medical Center, Durham, NC 27710, USA

2 Department of Anatomy, Cell Biology \& Physiology, Stark Neurosciences Research Institute, Indiana University School of Medicine, Indianapolis, IN 46202, USA receptors, as well as other classes of receptors, and the cellular context of these interactions ultimately determines the fate of neurons during neural development (e.g., survival, death, differentiation, axon growth). Interactions between neurotrophic factor receptor signaling pathways have been demonstrated in a variety of cellular contexts, including (1) indirectly, via integration of shared downstream signaling pathways; (2) directly, through ligand-dependent or ligand-independent interactions at the cell surface; and (3) through mechanisms involving receptor sorting, trafficking, or membrane localization. Here we provide a brief overview of neurotrophic factor receptor crosstalk with an emphasis on Ret, the receptor tyrosine kinase for the glial cell line-derived neurotrophic factor (GDNF) family of ligands (GFLs), for which all three of these mechanisms has recently come to light.

The GFLs are a family of neurotrophic factors distantly related to the transforming growth factor- $\beta$ (TGF- $\beta$ ) superfamily, consisting of four homologous members: GDNF, neurturin (NRTN), artemin (ARTN), and persephin (PSPN). The GFLs exert their functions by first binding as homodimers to lipid raft-localized glycophosphatidylinositol (GPI)-linked co-receptors known as the GDNF family receptor- $\alpha$ s (GFR $\alpha \mathrm{s})$, which then recruit and engage Ret. Each GFL has a preferred GFR $\alpha$ co-receptor, with GDNF preferentially binding to GFR $\alpha 1$, NRTN to GFR $\alpha 2$, ARTN to GFR $\alpha 3$, 
and PSPN to GFR $\alpha 4$, although cross-binding can occur (Airaksinen and Saarma 2002). Of note, GFL signaling is unique: Ret remains the only RTK identified to date which does not bind its ligands directly but instead requires a coreceptor for activation. This peculiarity thus confers additional opportunities to fine-tune GFL signaling through dynamic regulation of both Ret and GFR $\alpha$ s. Since the initial discovery of GDNF-Ret signaling as a critical regulator of kidney and enteric nervous system development in 1996 (Pichel et al. 1996; Sanchez et al. 1996; Schuchardt et al. 1994), the biological functions of Ret have been greatly expanded. In the nervous system, GFL-Ret signaling is now appreciated to play a critical role in the development of several populations of dorsal root ganglion (DRG) somatosensory neurons (Luo et al. 2007, 2009; Molliver et al. 1997) as well as geniculate oral sensory neurons (Donnelly et al. 2017), spinal motor neurons (Dudanova et al. 2010; Gould et al. 2008; Haase et al. 2002), postganglionic sympathetic and parasympathetic neurons (Durbec et al. 1996; Enomoto et al. 2001; Enomoto et al. 2000), orofacial trigeminal nociceptors (Donnelly et al. 2019), and even other populations as well. Ret has recently been found to be activated by growth differentiation factor 15 (GDF15), a metabolic regulator that binds to the co-receptor GFRAL and together engages Ret (Mullican et al. 2017; Yang et al. 2017). Whether Ret is the predominant signaltransducing receptor component underlying the effects of GDF15 on food intake and obesity is under investigation. Beyond normal physiological function, aberrant Ret signaling is also implicated in numerous cancers (Plaza-Menacho et al. 2014). Thus, an appreciation of the regulatory mechanisms governing GFL-Ret signal transduction has the capacity to inform our understanding of a variety of different developmental and disease processes.

\section{TGF- $\beta$ regulation of GFL signaling through GFRa1 surface localization}

Given the important biological functions carried out by the GFLs, it is perhaps not surprising that several mechanisms exist to precisely regulate GFL signaling through cell surface routing and membrane localization of the GFL receptor components. Interestingly, TGF- $\beta$ has an important role in the trophic functions of GDNF in developing neurons, both in vitro and in vivo. Krieglstein et al. demonstrated that GDNF-mediated survival of several developing peripheral and central neuron populations in vitro required the addition of TGF- $\beta$, and moreover, TGF- $\beta$ neutralizing antibodies could abolish GDNF-mediated neuronal survival (Krieglstein et al. 1998). In an in vivo model of adrenomedullectomy, removal of the adrenal gland induces the degeneration of preganglionic sympathetic neurons in the intermediolateral column of the spinal cord, and this degeneration can be reduced by the application of GDNF.
Interestingly, the neuroprotective effect of GDNF is abolished by the co-treatment of TGF- $\beta$ neutralizing antibodies with GDNF (Schober et al. 1999). Consistent with these models, co-application of GDNF and TGF- $\beta$ promotes the survival of developing sympathetic neurons of the chicken ciliary ganglion (CG), while neither factor on their own is able to promote survival (Peterziel et al. 2002). Of note, these effects are blocked by extracellular signal-regulated kinase (ERK) inhibition, but not by inhibition of the PI3 kinase (PI3K) pathway (Peterziel et al. 2002). While CG neurons are unresponsive to physiological concentrations of GDNF at baseline, TGF- $\beta$ pretreatment for $3 \mathrm{~h}$ is sufficient to induce GDNF responsiveness without requiring TGF- $\beta$ to continue to be present along with GDNF. In fact, after pretreatment with TGF- $\beta$, the complete elimination of TGF- $\beta$ using function-blocking antibodies in combination with GDNF does not alter the survival effects of GDNF (Peterziel et al. 2002). Mechanistically, TGF- $\beta$ induces the cell surface localization of GFR $\alpha 1$ without affecting either GFR $\alpha 1 \mathrm{mRNA}$ or protein levels (Peterziel et al. 2002). NRTN, in contrast, was found to promote the survival of developing $\mathrm{CG}$ neurons in the absence of TGF- $\beta$, and disrupting TGF- $\beta$ signaling using a pharmacological inhibitor of TGF- $\beta$ Receptor 2 (Tgfrb2) failed to attenuate NRTN-mediated survival (Peterziel et al. 2007). Consistent with these data, TGF- $\beta$ induced the recruitment of GFR $\alpha 1$ to the cell surface but did not recruit GFR $\alpha 2$, which was already abundantly localized to the cell surface (Peterziel et al. 2007). Taken together, TGF- $\beta$ is uniquely involved in GDNF signal transduction via a TGF- $\beta / \operatorname{Tgfrb} 2 /$ MAPK pathway that promotes the trafficking of GFR $\alpha 1$ to the plasma membrane (Fig. 1). To date, it remains unknown whether TGF- $\beta$ affects localization of the other two GFL receptor complexes (e.g., Ret, GFR $\alpha 3$, GFR $\alpha 4$ ) and mechanistically how TGF- $\beta$-mediated MAPK activation triggers the movement of internal stores of GFR $\alpha 1$ to the cell surface.

\section{Shutting off the signal: GDNF, GFRa1, and Ret trafficking by SorLA}

Although considerable progress has been made in our understanding of GFL receptor signaling and its downstream consequences, less is known about how ongoing GDNF-GFR $\alpha 1$ Ret signaling is extinguished at the molecular level. On this note, the sorting receptor SorLA was recently demonstrated to have a critical role. Using heterologous cell lines, it has been reported that the proteolytic processing of proGDNF to mature GDNF that occurs during transit through the secretory pathway requires SorLA (Geng et al. 2011). SorLA binds directly to both proGDNF via the prodomain and to mature GDNF, although the association with mature GDNF is lost at the acidic conditions present in the Golgi apparatus, whereas SorLA binding to proGDNF was retained (Geng et al. 2011). In addition, SorLA regulated the secretion of GDNF 
Fig. 1 TGF- $\beta$ regulation of GDNF-Ret signal transduction through GFR $\alpha 1$ cell surface localization

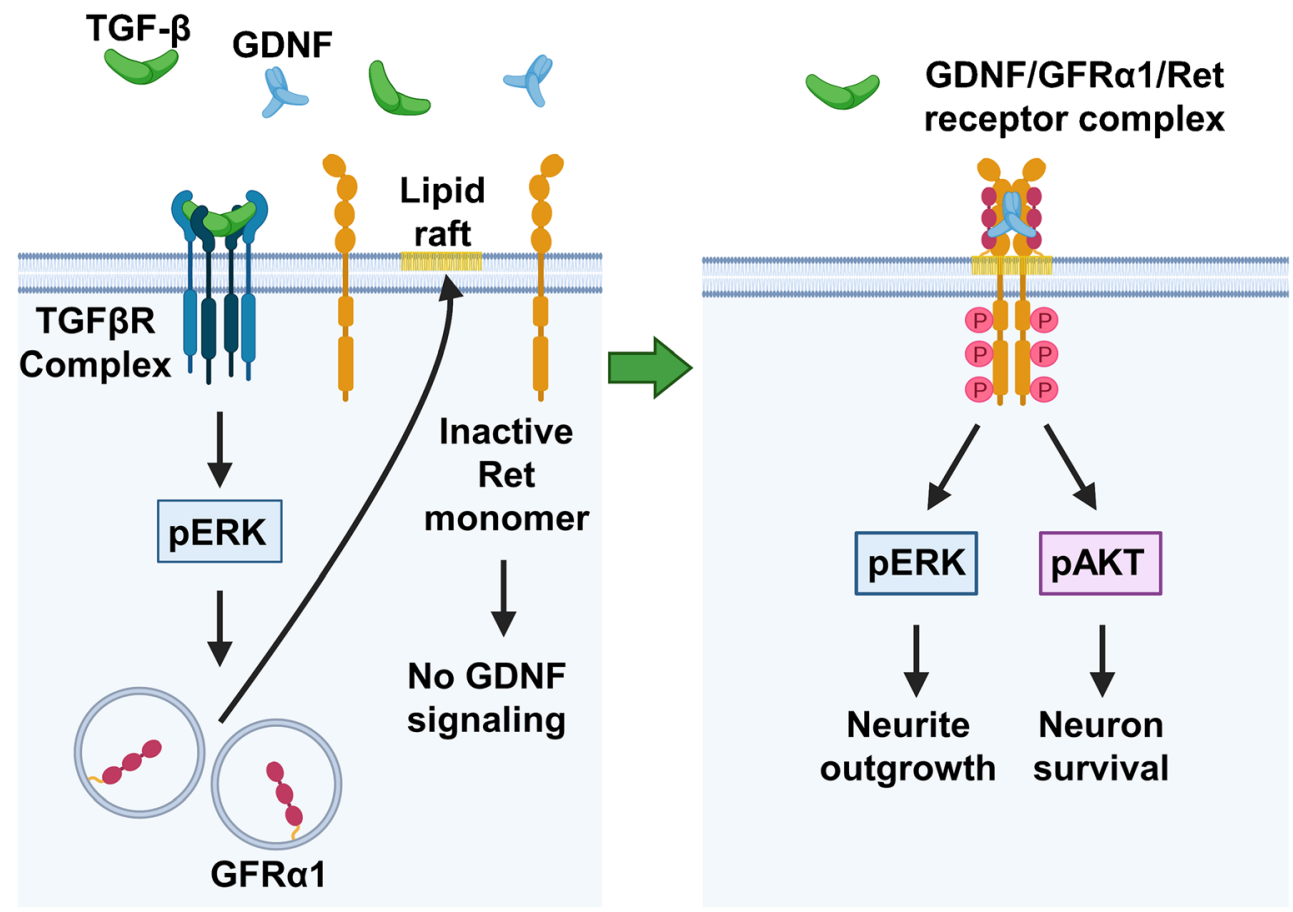

from the regulated secretory pathway stimulated by synaptic activity, but not GDNF release from the constitutive pathway (Geng et al. 2011). Following these observations, it was discovered that SorLA binds to GFR $\alpha 1$ with very high affinity and that SorLA is capable of binding to GFR $\alpha 1$ and GDNF simultaneously (Glerup et al. 2013). Interestingly, SorLA does not bind to the other GFLs, indicating that this mechanism selectively regulates GDNF signaling (Glerup et al. 2013). Upon binding, SorLA mediates internalization of GDNF and GFR $\alpha 1$ and promotes GDNF routing to lysosomes for subsequent degradation, while the GFR $\alpha 1 /$ SorLA complex escapes degradation. In addition, the SorLA/GFR $\alpha 1$ sorting complex promotes the endocytosis of Ret, even in the absence of GDNF, thereby sequestering it from subsequent activation and signal transduction (Glerup et al. 2013). Consistent with these findings, cultured hippocampal neurons lacking SorLA exhibited elevated cell surface levels of GFR $\alpha 1$, and GDNF was retained on the cell surface, in contrast to the rapid internalization of GDNF and its degradation in neurons expressing SorLA (Glerup et al. 2013). Importantly, SorLA ${ }^{-/}$mice display anatomic and functional abnormalities of dopaminergic midbrain circuits, such as elevated levels of GDNF in the midbrain and striatum, a marked loss of nigrostriatal connectivity, a blunted response to amphetamines, significant hyperactivity, and reduced anxiety levels (Glerup et al. 2013). These studies raise the possibility that SorLA could function to restrict GDNF/GFR $\alpha 1 /$ Ret signaling to specific subcellular regions. SorLA is reported to be predominantly located in cell bodies, dendrites, and initial segments but is excluded from distal axons and terminals (Glerup et al. 2013; Posse De
Chaves et al. 2000). This would result in the clearance of GFR $\alpha 1$ and Ret from the cell surface of the somatodendritic compartment, thereby only allowing for GDNF-mediated Ret activation to occur in axons. Furthermore, the function of SorLA in the regulated secretion of GDNF would allow for the activity-dependent release of GDNF from dendrites while avoiding autocrine activation of Ret in these same regions. Additionally, it is tempting to speculate that the ability of TGF- $\beta$ to promote the routing of intracellular GFR $\alpha 1$ to the cell surface could be due to an inhibition of SorLA activity.

\section{Bypassing the surface regulation of co-receptors: Ret activation by GFRas in trans}

Cells that express Ret usually also express one or more GFR $\alpha$ co-receptor. Interestingly, GFR $\alpha$ s, especially GFR $\alpha 1$, have considerably more widespread expression compared to Retexpressing cells. This led to the speculation that GFR $\alpha \mathrm{s}$ expressed in Ret-negative cells signal via receptors other than Ret, or that GFR $\alpha$ s, when bound to the appropriate GFL, can activate Ret in trans (in trans relative to Ret expression), in a cell non-autonomous manner. Evidence for the former possibility has emerged, and NCAM and syndecan-3 are both alternative signal-transducing receptors for GDNF (Bespalov et al. 2011; Paratcha et al. 2003).

Evidence supporting the physiologic role for GFR $\alpha$ function in trans has been more complex. The first issue to consider is whether GFR $\alpha$ co-receptors are capable of activating Ret in trans. Indeed, several studies indicate that soluble GFR $\alpha$ s, as well as GFR $\alpha$ co-receptors immobilized onto 
surfaces, such as charged beads, potently activate Ret and support survival, neurite outgrowth, axon guidance, and migration (Ledda et al. 2002; Paratcha et al. 2001). This is especially true in 3-dimensional culture systems such as DRG explants and ex vivo gut systems (Fleming et al. 2015; Patel et al. 2012). Cell lines, primary neurons, and various neural explants release soluble GFR $\alpha$ s into the culture medium, presumably by cleavage of the GPI anchor or by proteolysis, also supporting the possibility that GFR $\alpha$ s are shed from cell surfaces and act in trans (Fleming et al. 2015; Paratcha et al. 2001; Tsui et al. 2015). It is difficult to unequivocally prove, however, that the appearance of soluble GFR $\alpha$ s in tissue culture medium is not due to the stress of dissecting/dissociating the neurons or due to cell death ongoing in the cultures resulting in cell lysis and the accumulation of GFR $\alpha$ s in the medium.

In regard to whether trans signaling occurs in vivo, this has been most thoroughly investigated for GFR $\alpha 1$, and a transgenic mouse was produced to directly evaluate this possibility. In this mouse, GFR $\alpha 1$ is only expressed in cis in neurons that express Ret by transgenically driving GFR $\alpha 1$ in Ret+ cells in a GFR $\alpha 1$ null background, known in the field as the "cis-only" mouse $\left(\operatorname{Ret}^{\mathrm{GFR} \alpha 1 /+}\right.$; GFR $\left.\alpha 1^{-/-}\right)$(Enomoto et al. 2004). Quite remarkably, all of the most dramatic GDNF/GFR $\alpha 1$ functions, such as kidney morphogenesis, enteric nervous system development, and motor axon growth and guidance, were normal despite the extensive trans expression of GFR $\alpha 1$ in these regions (Enomoto et al. 2004). Subsequent studies, however, have provided compelling evidence that trans signaling by GFR $\alpha 1$ can occur in vivo. Perineural invasion of some cancers is induced by GDNF, and in vivo models of perineural invasion of sciatic nerve are eliminated when Ret is silenced in the transplanted cancer cells (He et al. 2014). Importantly, elimination of GFR $\alpha 1$ in these same cells reduces, but does not eliminate, their invasive properties, suggesting that GFR $\alpha 1$ expressed in the nerve in trans is sufficient (He et al. 2014). In another study, when GFR $\alpha 1$ was transgenically overexpressed in the striatum, there was a decrease in the programmed cell death of mesencephalic dopamine neurons that innervate this target, suggesting an enhancement of trans signaling (Kholodilov et al. 2011). In the DRG, some rapidly adapting (RA) mechanoreceptors express Ret and GFR $\alpha 2$, and deletion of Ret results in a dramatic loss of the central projections of sensory axons into the dorsal spinal cord (Fleming et al. 2015). Curiously, deletion of GFR $\alpha 2$ results initially in a complete loss of this innervation during early embryonic ages, but this deficit eventually recovers by birth. This is due to a compensation of GFR $\alpha 1$ expressed in the spinal cord that functions in trans, along with GDNF, to guide RA axons to their correct location (Fleming et al. 2015). Deletion of GFR $\alpha 1$ alone has no effect on this process, however, suggesting that the ability of GFR $\alpha 1$ to function in trans in this context is compensatory and may not normally provide this function.
While GFR $\alpha 1$ cis-only mice do not have identified developmental deficits in the periphery, it was more recently discovered that these mice have a significant loss of GABAergic interneurons in the cerebral cortex (Canty et al. 2009). GABAergic interneurons populate the cortex by migrating tangentially from the ganglionic eminences, a process that requires GDNF and GFR $\alpha 1$ (Pozas and Ibanez 2005). Analysis of cortical interneurons in cis-only mice revealed that there are large regions of the cortex where parvalbuminexpressing $(\mathrm{PV}+)$ interneurons were absent, called "PV holes." Indeed, it appears that these regions are devoid selectively of PV+ interneurons, whereas other classes of GABAergic neurons, such as somatostatin-expressing and calreticulin-expressing neurons, are normal (Canty et al. 2009). Interestingly, this tangential migration does not require Ret or NCAM, but does require the transmembrane heparin sulfate proteoglycan syndecan-3, suggesting that this is more likely to be a deficit in GDNF/GFR $\alpha 1$ function in PV+ neurons rather than a specific loss of trans signaling (Bespalov et al. 2011; Pozas and Ibanez 2005). Considering the data collectively, multiple lines of evidence indicate that GFR $\alpha$ co-receptors provided non-cell autonomously that can activate Ret, and trans signaling is likely to be involved in developmental functions such as axon growth and guidance, as well as cell migration.

\section{Neurotrophic factor receptor crosstalk: reciprocal interactions between Ret and TrkA}

While initially TrkA and Ret were understood to largely promote the survival of distinct, non-overlapping populations of neurons, it has come to be recognized that considerable crosstalk occurs between these two receptors. During peripheral nervous system development, TrkA and Ret are coexpressed in several populations of peripheral neurons at birth, including sympathetic neurons of the superior cervical ganglion (SCG) and in an actively differentiating population of dorsal root ganglion (DRG) nociceptors (Lallemend and Ernfors 2012). Perinatally, both populations are highly dependent upon target-derived NGF for their survival. Thus, what function does Ret serve in these neurons? Interestingly, phosphorylation of Ret increases with age in sympathetic neurons, both in vitro and in vivo, and in a manner which is both GFLand GFR $\alpha$-independent (Tsui-Pierchala et al. 2002). Instead, this effect was found to be dependent on NGF/TrkA signaling and required several hours to induce maximal Ret activation. This NGF-induced Ret phosphorylation only occurred in mature neurons (21 days in vitro; DIV) and not immature sympathetic neurons ( $5 \mathrm{DIV}$ ) that are analogous to neurons in their period of programmed cell death (Tsui-Pierchala et al. 2002). Interestingly, in mature primary sympathetic neurons, Ret contributed to the trophic functions of NGF, as $\operatorname{Ret}^{-/}$neurons exhibited somal atrophy, reduced metabolic status, and 
a

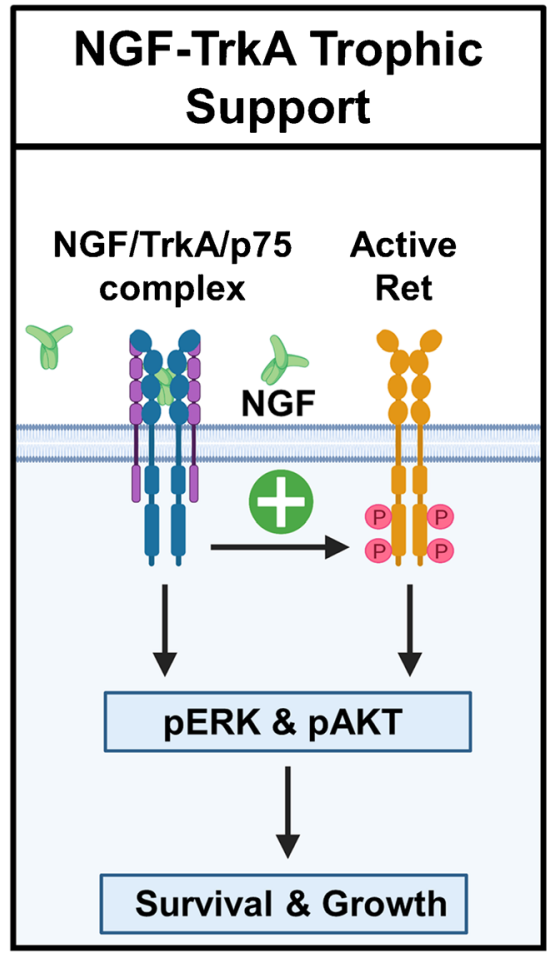

Fig. 2 a NGF/TrkA/p75 receptor complexes in mature sympathetic neurons promote Ret signaling by retaining autophosphorylated Ret on the cell surface. b In developing nociceptors, GDNF/Ret signaling inhibits TrkA signaling triggering the switch from TrkA+ peptidergic nociceptors to Ret+ nonpeptidergic nociceptors. In addition, p75 in
C

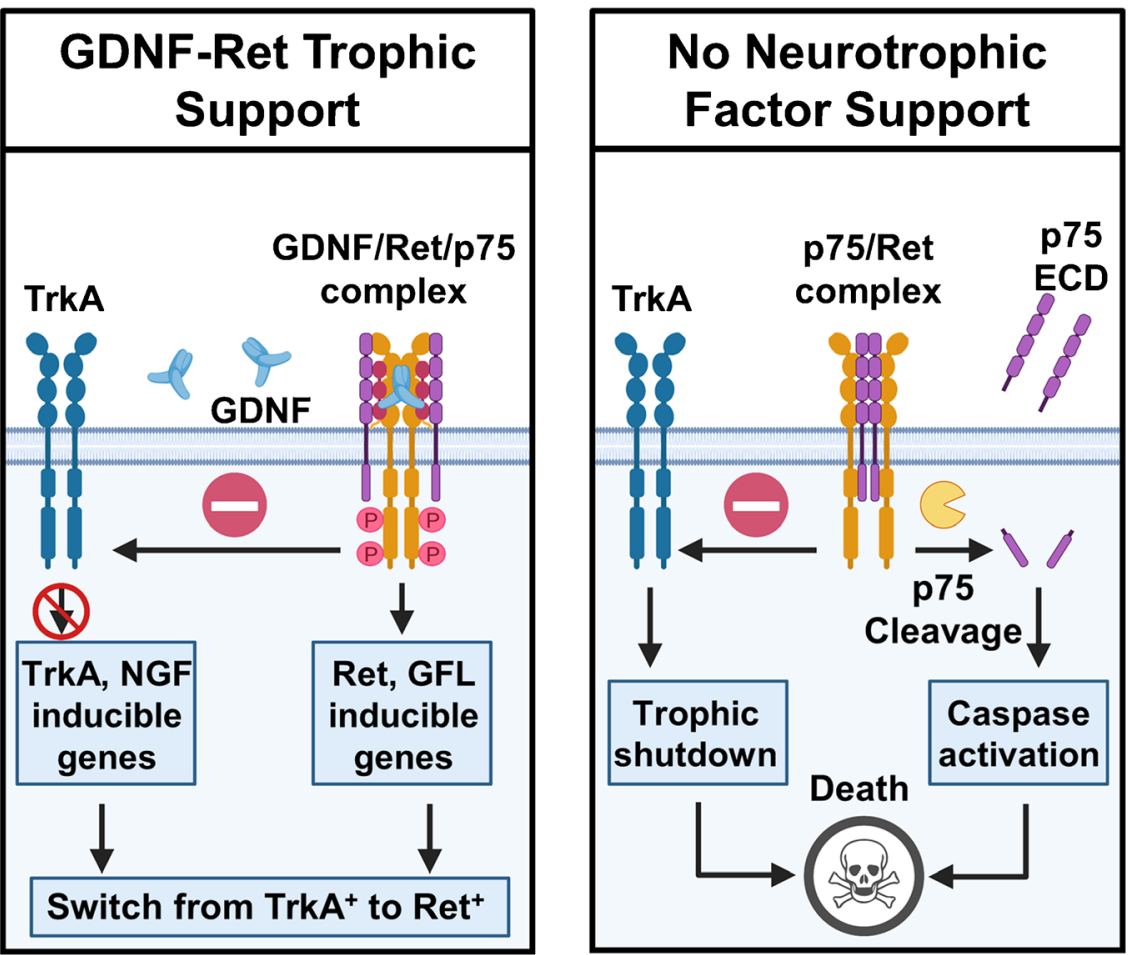

these neurons enhances Ret signaling and function. $\mathbf{c}$ In developing sympathetic neurons, Ret enhances the pro-apoptotic activity of p75 by enhancing TrkA degradation, thereby inhibiting NGF/TrkA survival signaling, while simultaneously enhancing pro-apoptotic death signaling of $\mathrm{p} 75$ by promoting its intramembranous cleavage substantially reduced expression of several critical NGFinducible genes (Tsui-Pierchala et al. 2002). In a later study, we reported that NGF promotes GFL-independent Ret activation via a mechanism by which NGF suppressed Ret internalization and degradation, leading to an accumulation of autophosphorylated Ret on the cell surface (Pierchala et al. 2007). Mechanistically, NGF promoted monoubiquitination of Ret, which remained on the cell surface, while GDNF activation of Ret promoted its polyubiquitination, which triggered the rapid internalization and degradation of P-Ret (Pierchala et al. 2007). Thus, NGF/TrkA signaling serves as a surprising positive regulator which strengthens Ret signaling in a GFL-independent manner (Fig. 2a). Interestingly, TrkA phosphorylation is retained for hours after NGF withdrawal in mature neurons, as compared to the rapid loss of phosphorylated TrkA after NGF deprivation in immature neurons (TsuiPierchala and Ginty 1999). Whether this occurs via the same mechanism by which NGF modulates Ret phosphorylation is currently unknown.

The aforementioned studies indicate that, at least in some cell types such as maturing sympathetic neurons, NGF potentiation of Ret signaling can be self-serving wherein Ret reciprocally promotes NGF-mediated trophism, likely through convergence of shared downstream signaling pathways (e.g., MAPK, PI3K). This is likely to be dependent on cell type and on the developmental time period. Within the first 2 weeks after birth, a subpopulation of immature $\operatorname{TrkA}^{+}$DRG nociceptors undergoes differentiation to form two broad populations: peptidergic nociceptors, characterized by their production of calcitonin gene-related peptide (CGRP) and their sustained expression of TrkA, and non-peptidergic nociceptors, characterized by their lack of CGRP expression, their affinity to bind isolectin-B4 (IB4), and their sustained expression of Ret (Molliver et al. 1997). Interestingly, during this diversification process, the emergence of Ret and the GFR $\alpha$ co-receptors is dependent NGF. In DRG nociceptors, Ret promotes the induction of unique gene subsets that are characteristic of non-peptidergic nociceptors, as well as autoregulation of its GFR $\alpha$ co-receptors (Luo et al. 2007). Importantly, Ret was also found to promote postnatal extinction of TrkA expression in these neurons, thereby promoting further diversification of these two populations to yield two molecularly and functionally distinct classes of nociceptors (Luo et al. 2007). Taken together, during postnatal development, there are at least two very different mechanisms of reciprocal signaling between TrkA and Ret. In mature 
sympathetic neurons, NGF drives Ret autophosphorylation, and not GFLs, which in turn augments the trophic effects of NGF, in contrast to postnatal DRG neurons in which NGF drives Ret expression and GFLs promote Ret activation, which in turn downregulates TrkA expression and upregulates genes necessary for the diversification of non-peptidergic nociceptive neurons (Fig. 2a, b).

\section{Neurotrophic factor receptor crosstalk: p75 as a rheostat for GFL-Ret signaling}

$\mathrm{p} 75$, also known as the $\mathrm{p} 75$ neurotrophin receptor $\left(\mathrm{p} 75^{\mathrm{NTR}}\right)$, is an enigmatic receptor whose functions depend heavily upon the cellular context of activation. Although originally identified as a receptor for NGF, p75 is now appreciated to bind all four neurotrophins with high affinity, as well as the unprocessed neurotrophins (pro-neurotrophins) with higher affinity (Ibanez and Simi 2012). In addition, p75 can augment survival signaling of all three Trk receptors, although the mechanism underlying this phenomenon remains incompletely understood. Interestingly, building on the above mechanism wherein TrkA promotes the expression of Ret, which subsequently promotes extinction of TrkA, p 75 was recently discovered to be critical in this process. Conditional deletion of $\mathrm{p} 75$ in sensory neurons beginning at E12.5 using Islet1-Cre led to a significant loss of Ret-dependent non-peptidergic nociceptors by adulthood, without affecting survival of any Trk-dependent DRG neuron populations (Chen et al. 2017). These losses were particularly drastic in non-peptidergic subpopulations expressing low levels of Ret $\left(\mathrm{MrgA}^{+}\right.$and $\left.\mathrm{MrgB}^{+}\right)$where greater than $50 \%$ of neurons were lost, as opposed to the Ret $^{\text {high }} \mathrm{MrgD}^{+}$population which lost only $\sim 25 \%$ of neurons (Chen et al. 2017). Ret $^{+}$mechanoreceptive neurons that emerge embryonically were not affected, similar to the other mechanoreceptive populations (Chen et al. 2017). p75 is required for GDNF- and NRTN-mediated survival in $\mathrm{Ret}^{+}$nonpeptidergic nociceptors in vitro. Consistent with this, p75 is required GDNF-mediated Ret activation and for the cell surface localization of Ret in cultured DRG nociceptors (Chen et al. 2017). Thus, in the reciprocal crosstalk between TrkA and Ret, p75 appears to act as a rheostat to fine-tune GFL-Ret signaling (Fig. 2b). In this model, p75 potentiates Ret activation and downstream signaling through enhanced cell surface routing, which is of particular consequence to neurons that have low basal levels of Ret expression.

\section{Neurotrophic factor receptor crosstalk: signal integration and coincidence detection in neuronal survival and death}

In addition to the trophic functions of $\mathrm{p} 75$ in potentiating Ret and Trk signaling as a co-receptor, a plethora of literature also supports the notion that $\mathrm{p} 75$ is also critically involved in programmed cell death (PCD) (Ibanez and Simi 2012). In mice lacking $\mathrm{p} 75$, the number of sympathetic SCG neurons is substantially increased, and the rate of apoptosis following NGF deprivation is diminished (Bamji et al. 1998). One model that has emerged to explain the temporal kinetics of PCD in the SCG is the "competition factor hypothesis," in which neurons receiving adequate trophic support (NGF) are protected from cell death and themselves upregulate and release proapoptotic p75 ligands which induce apoptosis in nearby neurons receiving inadequate trophic support (Deppmann et al. 2008). In the SCG, BDNF and proBDNF have been demonstrated to trigger apoptosis, owing to the lack of TrkB expression (Bamji et al. 1998; Deppmann et al. 2008; Teng et al. 2005). Interestingly, Ret is expressed in embryonic SCG neurons during PCD and, using a pulse-chase genetic strategy to label $\operatorname{Ret}^{+}$neurons, it was discovered that these $\operatorname{Ret}^{+}$neurons are rapidly eliminated (Donnelly et al. 2018). p75 and Ret physically associate, both in vitro and in vivo, and this interaction is enhanced by pro-apoptotic p75 ligands (Donnelly et al. 2018). Conditional deletion of Ret from primary sympathetic neurons in vitro enhances NGF-mediated survival and inhibits p75/BDNF-mediated apoptosis. Critically, tamoxifen-triggered conditional deletion of Ret or p75 (selectively in $\mathrm{Ret}^{+}$neurons) during PCD significantly reduced apoptosis and increased SCG neuron numbers, indicating that Ret and p75 collaborate in vivo to induce the apoptosis of "unsuccessful" sympathetic neurons (Donnelly et al. 2018). Mechanistically, Ret potentiates apoptosis through two distinct but interrelated mechanisms. First, Ret inhibits TrkA activation and downstream signaling via enhancing TrkA ubiquitination and subsequent degradation (Donnelly et al. 2018). Second, Ret enhances intramembranous cleavage of p75, potentiating activation of downstream pro-apoptotic effectors (Fig. 2c) (Donnelly et al. 2018). The functions of Ret in sympathetic neurons during PCD represents another example of Ret-mediated antagonism of TrkA signaling, as in DRG neuron diversification, underscoring the utility of this mechanism in both neuron differentiation and apoptosis (Fig. 2). In addition, the observation that a common p75-Ret signaling complex can promote either survival or apoptosis also aptly emphasizes the importance of cellular context (e.g., cell type, developmental stage, and trophic status). During PCD in the SCG, Ret functions essentially to "push neurons over the edge" that are not getting sufficient NGF support. As NGF signaling declines in these neurons, Ret is upregulated, thereby making $\mathrm{p} 75$ more effective at triggering apoptosis while at the same time inhibiting any remaining TrkA signaling. The apoptotic function of Ret in developing sympathetic neurons raises the question of whether Ret acts as a dependence receptor, in which the binding of ligand (GFLs) induces kinase activity and downstream signaling cascades leading to survival, but in the absence of ligand Ret actively signals apoptosis (Bordeaux et al. 2000). While this is an alluring mechanism, in 
this context, Ret appears to act in concert with p75 to enhance p75-dependent apoptotic signaling. On a related note, it has recently been reported that the tyrosine kinase activity of TrkA is critical for apoptosis triggered by NGF withdrawal from sympathetic neurons (Feinberg et al. 2017), and whether Ret kinase activity is required its apoptotic function is an important unanswered question.

\section{Summary}

Trafficking GFL receptor components into, or out of, the plasma membrane has a potent influence on the function of these neurotrophic factors. Along with the regulation of Ret expression and degradation, these modulatory mechanisms are pervasive and critical for precise regulation of Ret signal transduction. Thinking of the GFL receptor complex not as a single entity, but as an essential part of a network of receptor crosstalk, may enable a more accurate view of how different cell types respond to combinations of growth factors during development and adulthood. These complex signaling interactions should also be considered when evaluating the potential physiologic and pathophysiologic roles of Ret, Trks, and p75 in cancers and neurodegenerative disorders.

Funding information C.R.D. is supported by NIH T32 GM008600. B.A.P. is supported by NIH R01 NS089585 and R01 DC015799.

\section{Compliance with ethical standards}

Conflict of interest The authors declare that they have no conflicts of interest.

Ethical approval This article does not contain any studies with animals.

Open Access This article is licensed under a Creative Commons Attribution 4.0 International License, which permits use, sharing, adaptation, distribution and reproduction in any medium or format, as long as you give appropriate credit to the original author(s) and the source, provide a link to the Creative Commons licence, and indicate if changes were made. The images or other third party material in this article are included in the article's Creative Commons licence, unless indicated otherwise in a credit line to the material. If material is not included in the article's Creative Commons licence and your intended use is not permitted by statutory regulation or exceeds the permitted use, you will need to obtain permission directly from the copyright holder. To view a copy of this licence, visit http://creativecommons.org/licenses/by/4.0/.

\section{References}

Airaksinen MS, Saarma M (2002) The GDNF family: signalling, biological functions and therapeutic value. Nat Rev Neurosci 3:383-394

Bamji SX, Majdan M, Pozniak CD, Belliveau DJ, Aloyz R, Kohn J, Causing CG, Miller FD (1998) The p75 neurotrophin receptor mediates neuronal apoptosis and is essential for naturally occurring sympathetic neuron death. J Cell Biol 140:911-923

Bespalov MM, Sidorova YA, Tumova S, Ahonen-Bishopp A, Magalhaes AC, Kulesskiy E, Paveliev M, Rivera C, Rauvala H, Saarma M (2011) Heparan sulfate proteoglycan syndecan-3 is a novel receptor for GDNF, neurturin, and artemin. J Cell Biol 192:153-169

Bordeaux MC, Forcet C, Granger L, Corset V, Bidaud C, Billaud M, Bredesen DE, Edery P, Mehlen P (2000) The RET protooncogene induces apoptosis: a novel mechanism for Hirschsprung disease. EMBO J 19:4056-4063

Canty AJ, Dietze J, Harvey M, Enomoto H, Milbrandt J, Ibanez CF (2009) Regionalized loss of parvalbumin interneurons in the cerebral cortex of mice with deficits in GFRalpha1 signaling. J Neurosci 29:10695-10705

Chen Z, Donnelly CR, Dominguez B, Harada Y, Lin W, Halim AS, Bengoechea TG, Pierchala BA, Lee K-L (2017) p75 is required for the establishment of postnatal sensory neuron diversity by potentiating Ret signaling. Cell Rep 21:707-720

Deppmann CD, Mihalas S, Sharma N, Lonze BE, Niebur E, Ginty DD (2008) A model for neuronal competition during development. Science 320:369-373

Donnelly CR, Shah AA, Mistretta CM, Bradley RM, Pierchala BA (2017) Biphasic functions for the GDNF-Ret signaling pathway in chemosensory neuron development and diversification. Proc Natl Acad Sci U S A 115:E516-E525

Donnelly CR, Gabreski NA, Suh EB, Chowdhury M, Pierchala BA (2018) Non-canonical Ret signaling augments p75-mediated cell death in developing sympathetic neurons. J Cell Biol 217:32373253

Donnelly CR, Shah AA, Suh EB, Pierchala BA (2019) Ret signaling is required for tooth pulp innervation during organogenesis. J Dent Res 98:705-712

Dudanova I, Gatto G, Klein R (2010) GDNF acts as a chemoattractant to support ephrinA-induced repulsion of limb motor axons. Curr Biol 20:2150-2156

Durbec PL, Larsson-Blomberg LB, Schuchardt A, Costantini F, Pachnis $\mathrm{V}$ (1996) Common origin and developmental dependence on c-ret of subsets of enteric and sympathetic neuroblasts. Development 122: 349-358

Enomoto H, Heuckeroth RO, Golden JP, Johnson EM Jr, Milbrandt J (2000) Development of cranial parasympathetic ganglia requires sequential actions of GDNF and neurturin. Development 127: 4877-4889

Enomoto H, Crawford PA, Gorodinsky A, Heuckeroth RO, Johnson EM $\mathrm{Jr}$, Milbrandt J (2001) RET signaling is essential for migration, axonal growth and axon guidance of developing sympathetic neurons. Development 128:3963-3974

Enomoto H, Hughes I, Golden J, Baloh RH, Yonemura S, Heuckeroth RO, Johnson EMJ, Milbrandt J (2004) GFRalpha1 expression in cells lacking RET is dispensable for organogenesis and nerve regeneration. Neuron 44:623-636

Feinberg K, Kolaj A, Wu C, Grinshtein N, Krieger JR, Moran MF, Rubin LL, Miller FD, Kaplan DR (2017) A neuroprotective agent that inactivates prodegenerative TrkA and preserves mitochondria. J Cell Biol 216:3655-3675

Fleming MS, Vysochan A, Paixao S, Niu J, Klein R, Savitt JM, Luo W (2015) Cis and trans RET signaling control the survival and central projection growth of rapidly adapting mechanoreceptors. eLife 4:126

Geng Z, Xu FY, Huang SH, Chen ZY (2011) Sorting protein-related receptor SorLA controls regulated secretion of glial cell linederived neurotrophic factor. J Biol Chem 286:41871-41882

Glerup S, Lume M, Olsen D, Nyengaard JR, Vaegter CB, Gustafsen C, Christensen EI, Kjolby M, Hay-Schmidt A, Bender D et al (2013) SorLA controls neurotrophic activity by sorting of GDNF and its receptors GFRalphal and RET. Cell Rep 3:186-199 
Gould TW, Yonemura S, Oppenheim RW, Ohmori S, Enomoto H (2008) The neurotrophic effects of glial cell line-derived neurotrophic factor on spinal motoneurons are restricted to fusimotor subtypes. J Neurosci 28:2131-2146

Haase G, Dessaud E, Garces A, de Bovis B, Birling M, Filippi P, Schmalbruch H, Arber S, deLapeyriere O (2002) GDNF acts through PEA3 to regulate cell body positioning and muscle innervation of specific motor neuron pools. Neuron 35:893-905

He S, Chen CH, Chernichenko N, He S, Bakst RL, Barajas F, Deborde S, Allen PJ, Vakiani E, Yu Z et al (2014) GFRalphal released by nerves enhances cancer cell perineural invasion through GDNFRET signaling. Proc Natl Acad Sci U S A 111:E2008-E2017

Ibanez CF, Simi A (2012) p75 neurotrophin receptor signaling in nervous system injury and degeneration: paradox and opportunity. Trends Neurosci 35:431-440

Kholodilov N, Kim SR, Yarygina O, Kareva T, Cho JW, Baohan A, Burke RE (2011) Glial cell line-derived neurotrophic factor receptor-alpha 1 expressed in striatum in trans regulates development and injury response of dopamine neurons of the substantia nigra. J Neurochem 116:486-498

Krieglstein K, Henheik P, Farkas L, Jaszai J, Galter D, Krohn K, Unsicker K (1998) Glial cell line-derived neurotrophic factor requires transforming growth factor-beta for exerting its full neurotrophic potential on peripheral and CNS neurons. J Neurosci 18:9822-9834

Lallemend F, Ernfors P (2012) Molecular interactions underlying the specification of sensory neurons. Trends Neurosci 35:373-381

Ledda F, Paratcha G, Ibanez CF (2002) Target-derived GFRalpha1 as an attractive guidance signal for developing sensory and sympathetic axons via activation of Cdk5. Neuron 36:387-401

Luo W, Wickramasinghe SR, Savitt JM, Griffin JW, Dawson TM, Ginty DD (2007) A hierarchical NGF signaling cascade controls Retdependent and Ret-independent events during development of nonpeptidergic DRG neurons. Neuron 54:739-754

Luo W, Enomoto H, Rice FL, Milbrandt J, Ginty DD (2009) Molecular identification of rapidly adapting mechanoreceptors and their developmental dependence on ret signaling. Neuron 64:841-856

Molliver DC, Wright DE, Leitner ML, Parsadanian AS, Doster K, Wen D, Yan Q, Snider WD (1997) IB4-binding DRG neurons switch from NGF to GDNF dependence in early postnatal life. Neuron 19:849-861

Mullican SE, Lin-Schmidt X, Chin C-N, Chavez JA, Furman JL, Armstrong AA, Beck SC, South VJ, Dinh TQ, Cash-Mason TD et al (2017) GFRAL is the receptor for GDF15 and the ligand promotes weight loss in mice and nonhuman primates. Nature Med 23: $1150-1157$

Paratcha G, Ledda F, Baars L, Coulpier M, Besset V, Anders J, Scott R, Ibanez F (2001) Released GFRal potentiates downstream signaling, neuronal survival, and differentiation via a novel mechanism of recruitment of c-Ret to lipid rafts. Neuron 29:171-184

Paratcha G, Ledda F, Ibanez CF (2003) The neural cell adhesion molecule NCAM is an alternative signaling receptor for GDNF family ligands. Cell 113:867-879

Patel A, Harker N, Moreira-Santos L, Ferreira M, Alden K, Timmis J, Foster K, Garefalaki A, Pachnis P, Andrews P et al (2012) Differential RET signaling pathways drive development of the enteric lymphoid and nervous systems. Sci Signal 5:ra55

Peterziel H, Unsicker K, Krieglstein K (2002) TGFbeta induces GDNF responsiveness in neurons by recruitment of GFRalpha1 to the plasma membrane. J Cell Biol 159:157-167
Peterziel H, Paech T, Strelau J, Unsicker K, Krieglstein K (2007) Specificity in the crosstalk of TGFbeta/GDNF family members is determined by distinct GFR alpha receptors. J Neurochem 103: 2491-2504

Pichel JG, Shen L, Sheng HZ, Granholm AC, Drago J, Grinberg A, Lee EJ, Huang SP, Saarma M, Hoffer BJ et al (1996) Defects in enteric innervation and kidney development in mice lacking GDNF. Nature 382:73-76

Pierchala BA, Tsui CC, Milbrandt J, Johnson EM Jr (2007) NGF augments the autophosphorylation of Ret via inhibition of ubiquitindependent degradation. J Neurochem 100:1169-1176

Plaza-Menacho I, Mologni L, McDonald NQ (2014) Mechanisms of RET signaling in cancer: current and future implications for targeted therapy. Cell Signal 26:1743-1752

Posse De Chaves EI, Vance DE, Campenot RB, Kiss RS, Vance JE (2000) Uptake of lipoproteins for axonal growth of sympathetic neurons. J Biol Chem 275:19883-19890

Pozas E, Ibanez CF (2005) GDNF and GFRalpha1 promote differentiation and tangential migration of cortical GABAergic neurons. Neuron 45:701-713

Reichardt LF (2006) Neurotrophin-regulated signalling pathways. Philos Trans R Soc Lond Ser B Biol Sci 361:1545-1564

Sanchez MP, Silos-Santiago I, Frisen J, He B, Lira SA, Barbacid M (1996) Renal agenesis and the absence of enteric neurons in mice lacking GDNF. Nature 382:70-73

Schober A, Hertel R, Arumae U, Farkas L, Jaszai J, Krieglstein K, Saarma M, Unsicker K (1999) Glial cell line-derived neurotrophic factor rescues target-deprived sympathetic spinal cord neurons but requires transforming growth factor-beta as cofactor in vivo. J Neurosci 19:2008-2015

Schuchardt A, D’Agati V, Larsson-Blomberg L, Constantini F, Pachnis V (1994) Defects in the kidney and enteric nervous system of mice lacking the tyrosine kinase receptor Ret. Nature 367:380-383

Teng HK, Teng KK, Lee R, Wright S, Tevar S, Almeida RD, Kermani P, Torkin R, Chen ZY, Lee FS et al (2005) ProBDNF induces neuronal apoptosis via activation of a receptor complex of p75NTR and sortilin. J Neurosci 25:5455-5463

Tsui CC, Gabreski NA, Hein SJ, Pierchala BA (2015) Lipid rafts are physiologic membrane microdomains necessary for the morphogenic and developmental functions of glial cell line-derived neurotrophic factor in vivo. J Neurosci 35:13233-13243

Tsui-Pierchala BA, Ginty DD (1999) Characterization of an NGF-PTrkA retrograde-signaling complex and age-dependent regulation of TrkA phosphorylation in sympathetic neurons. J Neurosci 19: 8207-8218

Tsui-Pierchala BA, Milbrandt J, Johnson EM Jr (2002) NGF utilizes cRet via a novel GFL-independent, inter-RTK signaling mechanism to maintain the trophic status of mature sympathetic neurons. Neuron 33:261-273

Yang L, Chang C-C, Sun Z, Madsen D, Zhu H, Padkjaer SB, Wu X, Huang T, Hultman K, Paulsen SJ et al (2017) GFRAL is the receptor for GDF15 and is required for the anti-obesity effects of the ligand. Nature Med 23:1158-1166

Publisher's note Springer Nature remains neutral with regard to jurisdictional claims in published maps and institutional affiliations. 